\title{
MEASURES TO ACHIEVE THE ENERGY EFFICIENCY IMPROVEMENT TARGETS IN THE MULTI- APARTMENT RESIDENTIAL SECTOR
}

\author{
M. Upitis ${ }^{1 *}$, I. Amolina², I. Geipele ${ }^{2}$, N. Zeltins ${ }^{3}$ \\ 1JSC "Development Finance Institution Altum" \\ 4 Dome Square, Riga, LV-1050, Latvia \\ E-mail: martins.upitis@altum.Iv \\ ${ }^{2}$ Riga Technical University, \\ Institute of Civil Engineering and Real Estate Economics, \\ 6 Kalnciema Str., Riga, LV-1048, LATVIA \\ ${ }^{3}$ Riga Technical University, Institute of Power Engineering \\ 12-1 Azenes Str., Riga, LV-1048, LATVIA \\ *e-mail: martins.upitis@altum.lv
}

Directive (EU) 2018/2002 of the European Parliament and of the Council amending Directive $2012 / 27 /$ EU on energy efficiency sets a target of $32.5 \%$ energy efficiency to be achieved by 2030 , with a possible upward revision in 2023 . The directive also stipulates that the obligation to achieve annual energy savings must continue to be met after 2020. In addition, a revised directive on the energy performance of buildings was adopted in May 2018. It includes measures to speed up the renovation of buildings and the transition to more energy-efficient systems, as well as to improve the energy efficiency of new buildings, thus using smart energy management systems [1].

Buildings consume the most energy and have the greatest energy saving potential. They are therefore crucial to achieving the European Union's energy saving targets. The EU allocated around 14 billion EUR to improve the energy efficiency of buildings in the period of 2014-2020, of which 4.6 billion EUR was intended for residential buildings. In addition, the Member States have earmarked 5.4 billion EUR of public co-financing for the improvement of all types of buildings, of which around 2 billion EUR is allocated to residential buildings.

Multi-apartment residential buildings in Latvia are in a technically unsatisfactory condition. In Latvia, the service life of multi-apartment residential buildings has been artificially extended. In addition, there is also the problem of reduced construction quality. Housing problems affect all layers of society, but they are most acute for low- and middle-income people. 
The aim of the research is to study, using the co-financing of the European Union Structural Funds, the activities performed during the renovation process of multi-apartment residential buildings in Latvia and to identify the shortcomings.

Keywords: Construction quality, energy efficiency, renovation of residential houses.

\section{INTRODUCTION}

In Latvia, the main volume of multiapartment buildings up to $75 \%$ is made up of standard residential houses built in the period from 1946 to 1993 . The average specific heat consumption for heating of these apartment buildings is $157 \mathrm{KWh} / \mathrm{m}^{2}$ per year (Ministry of Economics). The results of multi-apartment building renovation projects implemented in European countries and Latvia demonstrate that by performing complex insulation it is possible to reduce heat energy consumption for heating by $40-60 \%$ of the initial consumption [2].

Compliance with the established norms on energy efficiency of buildings and binding state priorities are topical for the national economy:

1. A comprehensive increase in energy efficiency has become a cornerstone of a country's energy independence.

2. Reduction of harmful $\mathrm{CO}_{2}$ emissions.

3. Improving the energy efficiency of the manufacturing and service sectors is a matter of both competitiveness and the quality of work and the environment.

4. Directive 2002/91/EC of the European Parliament and of the Council of 16 December 2002 on the energy performance of buildings, which is adopted by the Republic of Latvia, envisages an increase in energy efficiency to meet the Kyoto Protocol aimed to reduce $\mathrm{CO}_{2}$ emissions.

These requirements ensure sustainable economic development and prevention of further climate change [3].
Energy efficiency has gained a lot of prominence in recent debates on urban sustainability and housing policy due to its potential consequences for climate change. At the local, national and also international level, there are numerous initiatives to promote energy savings and the use of renewable energy to reduce the environmental burden. There is a lot of literature on energy savings and other forms of energy efficiency in housing [4].

The topicality of the research is determined by several aspects:

1. It is important for the owners of multiapartment residential buildings to reduce the costs of heat energy. There is a human natural tendency to live rationally and save heat energy and other resources, if one has to pay for them; thus, it leads to economical use of energy.

2. In the period from 1955 to 1992 , reinforced concrete structures were widely used in construction. The construction of buildings of this period is characterised by high specific energy consumption and low heat resistance of building envelopes.

3. Multi-apartment residential buildings constructed in the $50 \mathrm{~s}$ and $60 \mathrm{~s}$ are approaching the end of the normative service life; depreciation of engineering services of buildings is 70-100\%.

4. During the European Union funds planning period, apartment owners in multiapartment buildings have the oppor- 
tunity to receive co-financing for the implementation of energy efficiency improvement measures.

The goal of the research is to study the implementation of energy efficiency measures in multi-apartment residential buildings and the achieved indicators using the co-financing of the European Union Structural Funds.

To achieve the goal, the following objectives are set: 1) to study scientific articles on the chosen topic; 2) to find out the main achievable indicators in the implementation of the programme; 3 ) to find out the tools to make sure of the quality of construction work.

The subject of the research is energy efficiency measures for multi-apartment residential buildings, and the object of the research - multi-apartment residential buildings.

In the course of literature analysis, the authors have used topical articles of the Web of Science and Scopus scientific databases and unpublished information from state-owned development finance institute Altum.

\section{THE NATURE OF ENERGY EFFICIENCY}

The explanation of the concept of energy efficiency should be considered not only in Latvian, but also in the European Union (hereinafter - the EU) and global context. Definitions of energy and related concepts are provided both in Directive 2012/27/ EU of the European Parliament and of the Council of 25 October 2012 on energy efficiency, amending Directives 2009/125/EC and 2010/30/EU and repealing Directives 2004/8/EC and 2006/32/EC, and in regulatory enactments of the Republic of Latvia related to the energy sector.

Article 2 of Directive 2012/27/EU of the European Parliament and of the Council provides the following definition: "energy efficiency means the ratio of output of performance, service, goods or energy, to input of energy" [5].

Article 2 of Directive 2010/31/EU of the European Parliament and of the Council provides the following definition: "energy performance of a building means the calculated or measured amount of energy needed to meet the energy demand associated with a typical use of the building, which includes, inter alia, energy used for heating, cooling, ventilation, hot water and lighting" [6].

According to the Law on the Energy Performance of Buildings and the explanation of the Ministry of Economics of the Republic of Latvia, energy performance of a building is the relative amount of energy, which characterises the necessary energy consumption for the supply of heating, ventilation, cooling, lighting and hot water in the typical operating conditions of a specific type of building. The energy performance of a building is expressed in kilowatt hours per square meter per year $(\mathrm{kWh} / \mathrm{m} 2$ per year) [7].

In the course of the examination of the energy efficiency concept, the authors conclude that energy efficiency can be characterised as a change in values, which can manifest itself as both a reduction in energy consumption and an increase in the level of productivity. Energy efficiency is understood as the reduction in the amount of energy consumed - the difference between the identified energy consumption before the implementation of energy efficiency solutions and the calculated or determined energy consumption after the implementa- 
tion of energy efficiency measures.

Electricity consumption in energy efficiency projects is also important. Since the European Commission has suggested that all the EU Member States should discontinue season-dictated time changing, the economically best-grounded solution in terms of electricity consumption is the scenario where country chooses staying at summer time and the Nord Pool countries - at winter time. In the construction sector, summer time has a positive impact - considering the relatively short building season [8].

The concept of smart grid has received significant attention in recent times due to climate change sustainability, uses requirements of higher supply reliability and quality [9].

Most of the urban housing stock in Latvia as well as in the major part of EU cities consists of multi-storey apartment buildings. The improvement in energy efficiency of these buildings is the key priority in many countries. However, unclassified buildings have a significant potential for the application of innovative energy efficiency measures [10].

Although in littoral regions of the Baltic Sea in Latvia multi-storey residential buildings with a large number of apartment owners are not dominant, different opinions of the owners about the implementation of energy efficient solutions and their financial capacity impede the energy efficient process management. Often, apartment owners are not well informed and aware of the issues related to energy efficient solutions and energy efficient process, as well as of the management of joint ownership of houses; therefore, they passively take part in the decision-making process [11].

The EU Member States are in the process of implementing energy rating pro- cedures for buildings. For non-domestic buildings in particular, devising a robust and cost effective energy rating method is not a simple task. The situation becomes more complicated where countries do not have a tradition of performing energy calculations or undertaking energy measurements in buildings [12].

Buildings, which form the accumulated wealth of a country during a long time and are frequently the largest asset of each country, should be renovated, considering the benefit as well of the timely renewal of worn out building elements.

For example, the Energy Efficiency Housing Pilot Project in Lithuania, which was initiated by the World Bank and directed to the renovation of residential houses and educational institution buildings, has shown that at present, residential and public buildings built between 1960 and 1980 face two problems - an inefficient heat consumption and a deterioration of building elements and engineering systems. This in turn results in conditions inside buildings that do not comply with up-to-date requirements of comfort and safety [13].

In general, it can be concluded that the nature of energy efficiency and related activities in the process of renovation of multi-apartment buildings should be implemented using a model, which will increase the efficiency, comfort and exterior of a dwelling. Measures should be taken on the basis of high level energy audit results, determining the main problems, identifying the main causes of heat loss, during the renovation of the dwelling focusing on the main problems, which result in high heat loss from the dwelling, the main defects in the structures, the renovation of which will increase the life cycle of residential buildings. 


\section{DISCUSSION AND RESULTS}

In Latvia, a large part of multi-apartment residential buildings was constructed in the period from 1946 to 1993 [14]. These buildings are characterised by high wear and tear of building structures and engineering systems, as well as low energy efficiency. Since 2016, the support of the EU structural funds in the amount of 156 million EUR has been available in the country to renovate multi-apartment buildings ( $85 \%$ of the EU structural funds, $15 \%$ of state funding). It is envisaged that this funding will be enough for about 1,030 multi-apartment buildings. The implementer of the financial instrument in this period is JSC "Development Finance Institution Altum" [15]. Support in this programme is provided in the form of grants, loans, guarantees and advice (DME programme). The specific objective of the programme is to promote energy efficiency and the use of smart energy management and renewable energy in multi-apartment residential buildings. To receive the EU support within this programme, the heating consumption of a residential building after the performance of works shall not exceed $90 \mathrm{kWh} / \mathrm{m}^{2}$ per calendar year.

The average heat consumption for heating of multi-apartment residential buildings submitted to the DME programme is 155 $\mathrm{kWh} / \mathrm{m}^{2}$; information on the projects submitted to the DME programme until 15 October 2018 is summarised in Figs. 1 and 2.

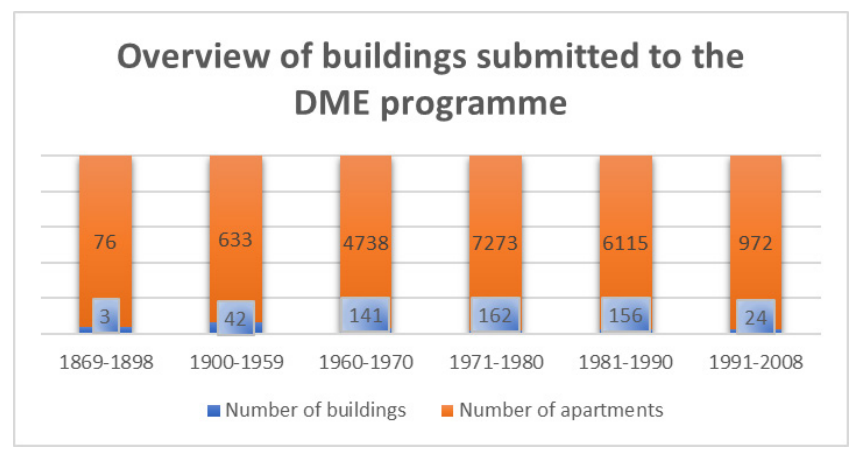

Fig. 1. The number of multi-apartment residential buildings and households (apartments) in the DME programme until 12 July 2020 (created by the authors using Altum information).

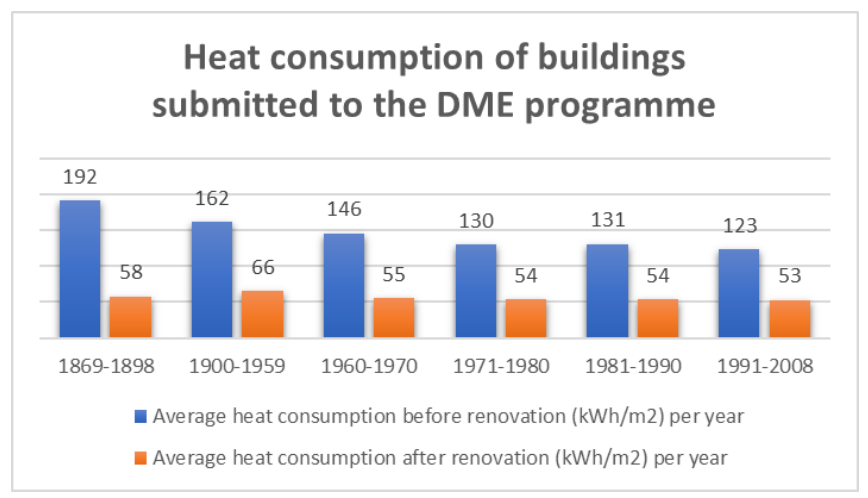

Fig. 2. Summary of current and planned average heat consumption per year of multi-apartment residential buildings before and after renovation of buildings (created by the authors using [14-16]). 
There are 38.6 thousand multi-apartment residential buildings (three- or more apartment buildings) in Latvia with a total area of 50.4 million $\mathrm{m}^{2}\left(1305 \mathrm{~m}^{2}\right.$ per building) [14]. It is possible to perform costeffective renovation of $60 \%$ to $70 \%$, or about 25 thousand apartment buildings with a total area of 38 million $\mathrm{m}^{2}$. A small part (3\% of the total number of houses 741 buildings) has been renovated in the EU funds programming period of 20072013, while the buildings built after 2003 (approximately $3 \%$ of the total number of buildings) are relatively energy efficient, with low energy consumption. The number of potentially energy efficient renewable buildings in Latvia is approximately 23,500
$(94 \%$ of 25,000$)$ with a total area of 30.6 million $\mathrm{m}^{2}$.

Latvia has set high targets in the field of energy efficiency. In order to increase the energy efficiency of multi-apartment buildings, a complex approach is required, reaching the specific heat consumption for heating in the amount of $70-90 \mathrm{kWh} / \mathrm{m}^{2} /$ year after the renovation of buildings (minimum requirements of the DME programme). To achieve such specific heat consumption, the project must achieve a total heat saving of $85 \mathrm{kWh} / \mathrm{m}^{2}$ on average. In turn, in order to achieve such heat energy savings, the investment costs per $\mathrm{m}^{2}$ of the total area of the building must be approximately 156 EUR (see Fig. 3 below).

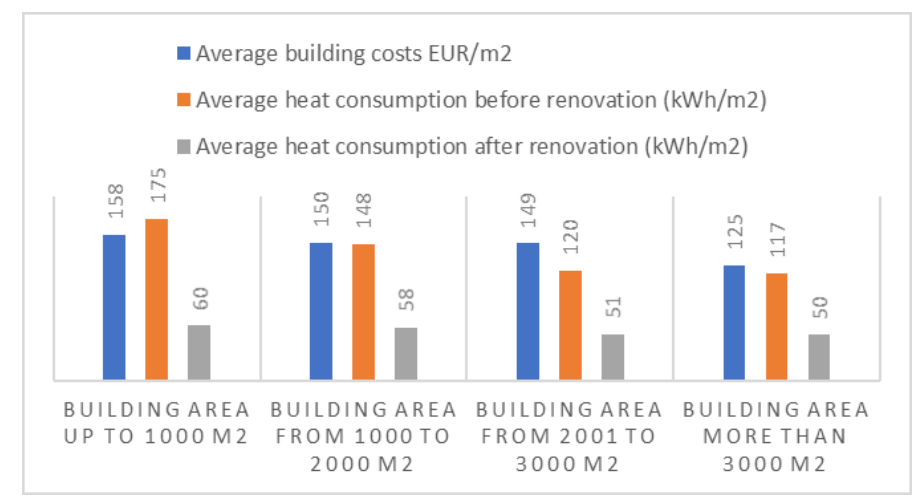

Fig. 3. Costs and heat consumption divided by the total $\mathrm{m}^{2}$ of the building (distribution by $\mathrm{m}^{2}$, up to 1000 , from 1000-2000, from 2001-3000, more than 3000) (created by the authors).

When implementing building renovation works, great emphasis is placed on high-quality technical project documentation, so that there would be as few unforeseen works as possible during the project implementation stage, which could have been foreseen at the design stage but were not performed. In order to qualitatively prepare the DME (energy efficiency of a multiapartment building) project, the following documents are required:

1. Building energy certificate;

2. Structure technical inspection opinion by a construction specialist;
3. Construction project drawn up by a construction specialist or a building facade confirmation card and work organisation project;

4. Certification card made by a construction specialist for engineering structures;

5. Construction volumes or control estimate.

Works that could provide energy efficiency are determined by the energy certificate of a building. The annex to the certificate indicates what work should be done to improve the overall energy performance of a building. 
Usually these works are related to the insulation of the building enclosing structures (building facade, plinth, and roof), basement insulation, attic insulation, replacement of windows and doors both in the apartments and in the staircase. Of course, one cannot forget about the renovation of the building engineering systems (heating and hot water) to ensure the regulation of heating consumption according to the wishes of each resident, so that each consumption can also be accurately accounted for, generally ensuring comfort in apartments.

Evaluating the construction contracts submitted to the DME programme, it has been established that mostly project implementation is not carried out according to the planned plan - Project Time Schedule.
As soon as it is established that deviations are planned and the construction deadlines are not met, it is necessary to amend the contract, including an agreement on the extension of the term of work. Below statistics is provided (see Fig. 4) on how many of the completed projects were on time, how many were not, or whether there was an extension of deadlines.

In order to extend the term of work, the builder needs to submit a substantiated application/letter to the customer and a new time schedule, while the customer draws up an affirmation act and an agreement within the contract. This information is then submitted to Altum, where the legal aspect and the requirements set out in the procurement regulations are assessed.

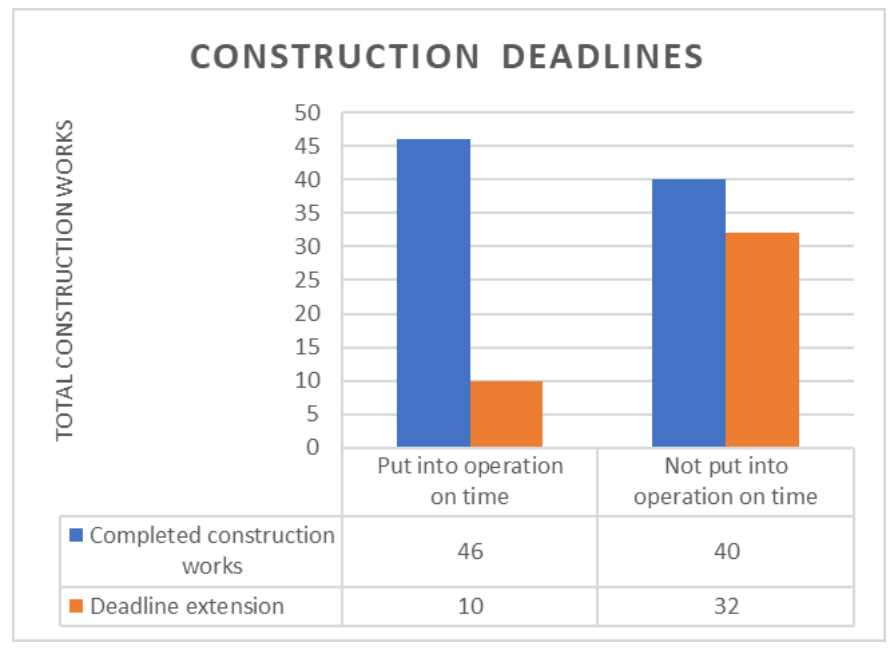

Fig. 4. Terms of the construction contract (created by the authors using Altum information).

There are several typical trends in the DME programme that recur, where the builder offers relatively short deadlines and is unable to meet them.

Construction works shall be carried out by a construction contractor registered in the Register of Construction Merchants. The supervision of the works is performed by a certified construction contractor, who makes daily entries in the construction work log regarding the performed works and the materials used. According to the construction completion deadlines (see Fig. 5), only 1 out of 30 projects has been completed within the planned deadline. 


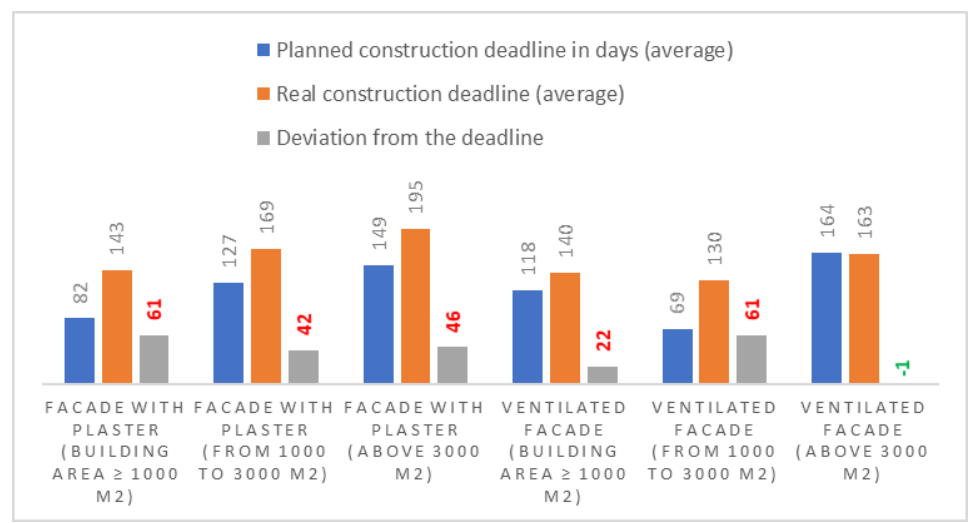

Fig. 5. Division by the planned and actual work execution (created by the authors using Altum information).

Construction companies, implementing DME projects even after several deadline extensions, cannot complete the work within the set deadlines. It is crucial that when concluding contracts in the autumn, but starting work in the spring next year, the entrepreneur faces a shortage of materials or rising material prices, which affect the purchase of materials and construction deadline.

To control the quality of construction work in terms of the energy efficiency of a building, a control tool - thermography with a thermal chamber - is often used. Using the infrared radiation generated by a building, the surface temperature of the structure is determined and plotted in a plane by means of a colour scale. This method allows quickly obtaining visual data on the quality of the work performed and it is not necessary to expose the defect site.

Thermography uses a qualitative test method, i.e., one surface is compared with another or with itself, thus identifying problem areas, but it is not possible to determine the flow of heat through the building surfaces, such as the heat transfer coefficient of a building element or building permeability.

The thermography method is more used in cases when the building envelope is insulated with a plastered facade solution. Another limitation of this test method is that the thermographic survey cannot be performed if the energy efficiency works in a building are carried out at a time when the temperature difference between the indoor and outdoor environment is insufficient to perform a qualitative survey (in summer).

In the DME programme, insulation of enclosing structures with a ventilated facade is used in some objects, which means that there is no direct thermal contact between the main structure of the exterior wall and the facade finishing material; as a result, it is not possible to fix the defect in the main structure. In such cases, in order to determine the quality of the work carried out, it is necessary to perform a building density test or BlowerDoor test.

The BlowerDoor test method works on the principle of creating a pressure difference of $50 \mathrm{~Pa}$ between the interior and the exterior of the building, thus determining the amount of outdoor air entering the structures through various leaks. The BlowerDoor tool consists of a calibrated fan air flow measurement and special measuring devices to determine the pressure difference between two measuring environments.

Tables 1 and 2 below summarise the images from the post-monitoring of the site, when the quality of the work performed is checked and a site is inspected where no renovation work has been carried out. In 
the thermography images, one can make sure that an uninsulated building has very large heat losses through external walls, old wooden windows, and window openings. According to the temperature scale in the thermography images, it can be seen that the building on the left has been renovated, exterior wall and loggia walls have been insulated. In the building on the right, there are visible heat losses both through the external walls and the window openings. The largest heat losses are observed in the joints of panels, window and door openings. Therefore, in the process of building renovation, it is important to pay attention to the quality of work, which is directly related to the joints of the building envelope, pretreatment of joints, anti-corrosion treatment of reinforcement, use of waterproofing mastic as well as insulation of windows and doorways, in order to reduce cold bridges.

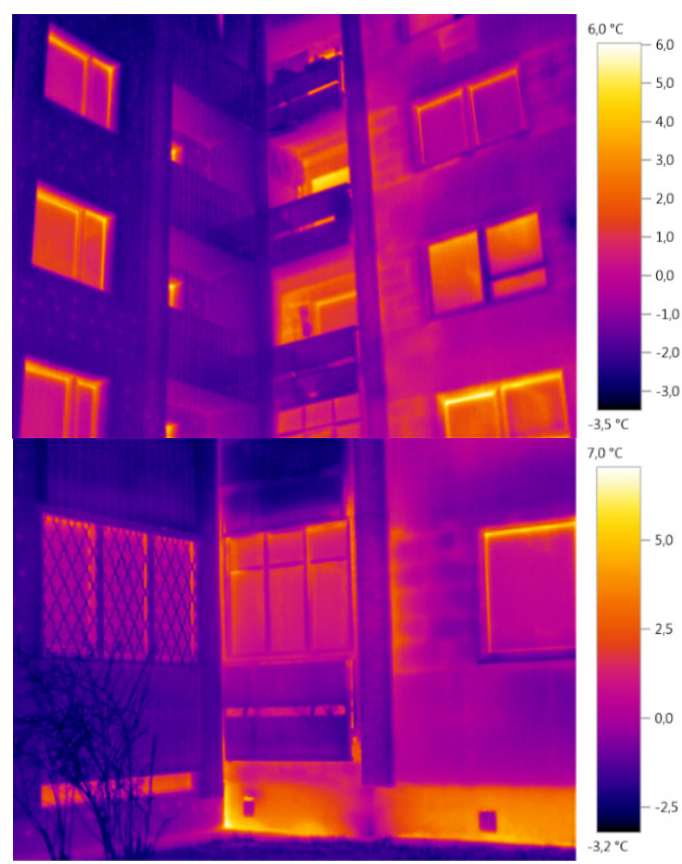

Fig. 6. Fixation from the work process (from the authors' archive).

In the "uninsulated building" (see Figs. serious heat losses.

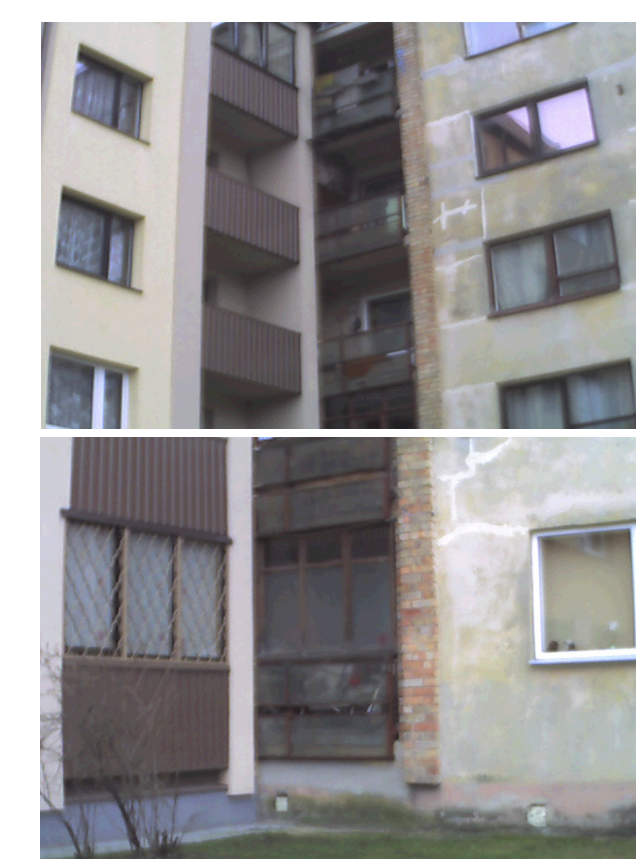

During inspections, it is often found that if the project does not provide for the transfer of gas inlets and electrical cabinets from the building facade, large heat losses are observed through parts of the building that are not insulated, where insulation material offset is formed, because these gas inlets or electrical cabinets are not allowed to be completely "insulated". Also in the photo fixation attached to the tables one can see the location of these problems, in the gas inlet that is not insulated, there is increased heat loss, the surface temperature is higher than it would be if the facade surface were completely insulated.

Figures 6 and 7 below summarise the images of insulated and uninsulated multiapartment residential buildings. It is possible to clearly see both thermography and photo fixation in the images. 
Uninsulated building

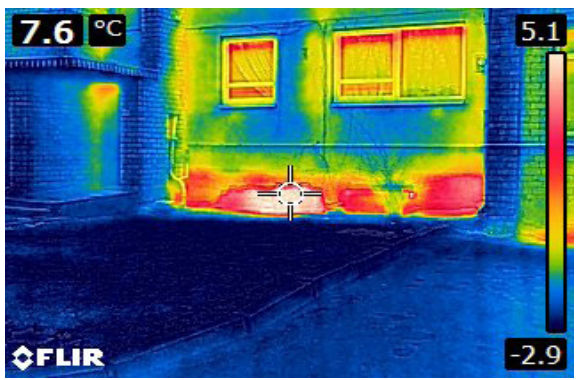

The left corner of the photo shows the temperature $\left(\mathrm{C}^{\circ}\right)$ where the target is fixed (in the center of the photo). It is fixed to the plinth of the building. The problem is in the plinth part of the building; the surface is heated to $+7.6 \mathrm{C}^{\circ}$, which means that the basement has an increased temperature, the enclosing structure has low heat resistance and heat energy escapes when the plinth of the building is heated.

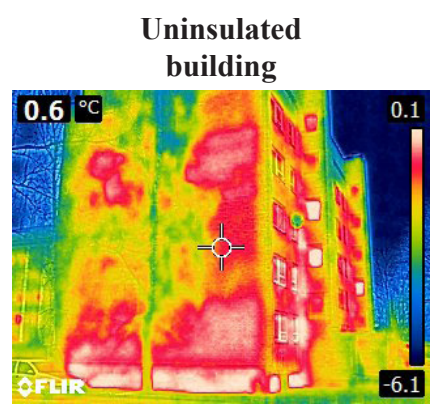

Uninsulated building

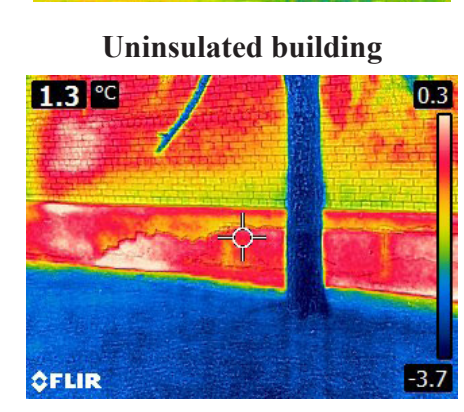

Insulated building

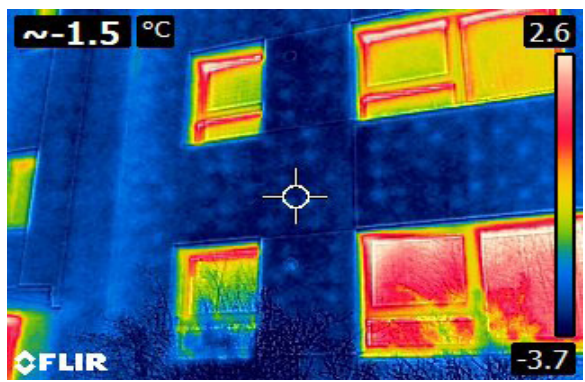

The photo shows that the insulated exterior wall has a high heat resistance; the high quality work has been performed. Questions could be asked here about the fastenings (dowels) of the thermal insulation material, as it can be observed they emit heat from the building structure.

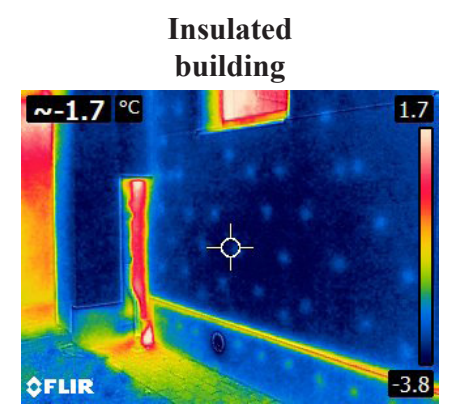

Insulated building

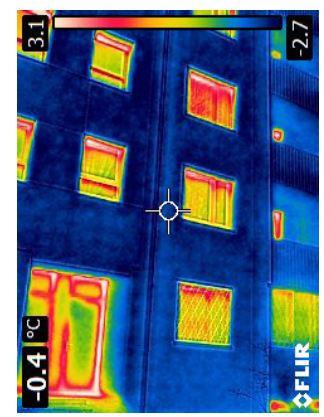

Insulated and uninsulated building

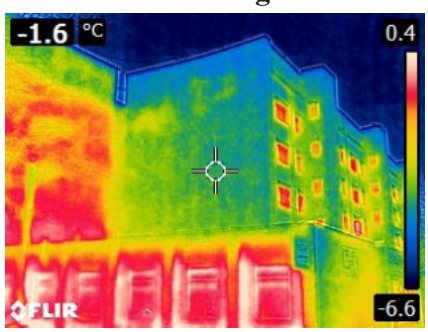

Insulated building

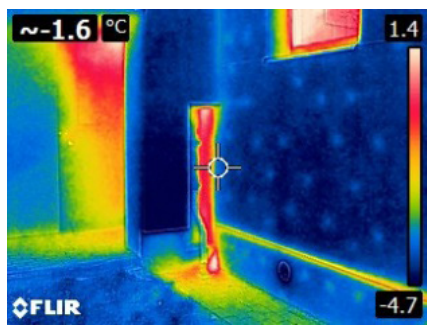

Fig. 7. Thermographs from building inspection (from the authors' archive).

Thermographic photographs show the intensity of heat loss through the enclosing structures of the building. The surface temperature can be compared to the outdoor air temperature. The closer the surface temperature is to the outdoor temperature, the better heat resistance properties of the surface (enclosing structure). Colour differences can also be accurately observed; the darker shade of blue colour, the better heat 
resistance values the construction has due to less heat permeation through the parts of the building, lower heat loss.

It should be noted that measures affecting one system or part of a building may affect the energy performance of another system and part of a building. For example, the insulation layer of the enclosing structure affects the capacity and dimensions of the engineering systems. This interaction between different activities is taken into account when determining a complex solution for the renovation of a building.

Therefore, in DME projects, the authors observe that building renovation measures are combined into a set of measures and options, because meaningful combinations of measures can create synergies, providing better results (in terms of cost and energy efficiency) than individual measures. If more cost-effective energy efficiency measures are included in the set of measures, this may provide an opportunity to include other measures that are not cost-effective but can significantly increase primary energy use and reduce $\mathrm{CO}_{2}$ emissions in relation to the overall building concept, provided, however, that the whole set of measures brings greater benefits than costs during the operation of the building or building elements. In turn, when implementing complex energy efficiency measures, it is also possible to improve the aesthetic parts of the building (staircases, porches, etc.).

\section{CONCLUSIONS}

To achieve the best possible result, it is necessary to develop the building renovation project in as much detail as possible, as well as to choose thermal insulation and finishing (plastered and ventilated facade) solutions, evaluating economic and technological aspects.

In the case of complex renovation of a building, the achieved energy savings, if both design and construction conditions are observed during the project implementation, shall be not less than $50 \%$ of the previous consumption.

The authors conclude that the current costs and the deadline for the preparation of technical documentation are not commensurate with the quality of the developed works. Most multi-apartment buildings are constructed according to standardised designs, so the design should be simpler, but with a comparatively finer approach to technical solutions, where attention should be paid to detail and the total investment costs should be calculated according to the energy saved.

Achieving a high-quality, cost-effective and energy-efficient result is based on the development of a standardised building renovation project with a detailed description of the economy and achievable energy efficiency indicators, which is explained to homeowners in order to better and more effectively meet owners' needs, reach lower utility costs and achieve energy efficiency indicators.

\section{ACKNOWLEDGEMENTS}

The research has been supported by the project of the National Research Programme "Trends, Challenges and Solutions of Latvian Gas Infrastructure Development" (LAGAS) (No. VPP-EM-INFRA2018/1-0003). 


\section{REFERENCES}

1. Amanaditis, G. (2020). Combating climate change. Available at https://www.europarl. europa.eu/factsheets/lv/sheet/72/cina-pretklimata-parmainam

2. Ėku energoefektīvas renovācijas koncepcija Juglai. (2010.) SIA Pilsētmāju pārvaldnieks. Available at http://www.rea.riga.lv/ files/urbenergy/Eku_energoefektivas renovacijas_koncepcija_Juglai_1dala.pdf

3. Savickis, J., Zemite, L., Bode, I., \& Jansons, L. (2020). Natural Gas Metering and its Accuracy in the Smart Gas Supply Systems. Latvian Journal of Physics and Technical Sciences, 57 (5), 39-50. DOI: 10.2478/lpts2020-0026

4. Nieboer, N., Gruis, V., Van Hal, A., \& Tsenkova, S. (2011). Energy efficiency in housing management-Conclusions from an international study. In ENHR Conference, 5-8 July 2011. Available at https://www. academia.edu/1782670/Energy_efficiency in_housing_management_conclusions_ from_an_international_study

5. Directive 2012/27/EU of the European Parliament and of the Council on energy efficiency, amending Directives 2009/125/ EC and 2010/30/EU and repealing Directives 2004/8/EC and 2006/32/ EC, 25.10.2012. Official Journal of the European Union. 14.11.2012. Available at https://eur-lex.europa.eu/legal-content/EN/ TXT/?uri=celex\%3A32012L0027

6. Directive 2010/31/EU of the European Parliament and of the Council of 19 May 2010 on the energy performance of buildings. Official Journal of the European Union. 18.06.2010. Available at https:// eur-lex.europa.eu/legal-content/en/ TXT/?uri=CELEX\%3A32010L0031

7. Ministry of Economics of the Republic of Latvia. (2018). Éku energoefektivitāte. Available at https://www.em.gov.lv/lv/ nozares_politika/majokli/eku_ energoefektivitate/

8. Jasevičs, A., Zemīte, L., Gorobecs, M., \& Klavina-Makrecka, S. (2019). The impact of season-dictated daylight saving measures on electricity consumption. In IEEE 60th Annual International Scientific Conference on Power and Electrical Engineering of Riga Technical University, RTUCON $2019-$ Proceedings. Article number 8982303. 7-9 October 2019, Riga, Latvia.

9. Jasevičs, A., Zemīte, L., \& Kuṇickis, M. (2017). Demand load control with smart meters. In 58th Annual International Scientific Conference on Power and Electrical Engineering of Riga Technical University, RTUCON 2017 - Proceedings, Vol. 2017-November (pp. 1-6). DOI: 10.1109/RTUCON.2017.8124757

10. Borodinecs, A., Geikins, A., \& Prozuments, A. (2020). Energy consumption and retrofitting potential of latvian unclassified buildings. Sustainability in Energy and Buildings: Proceedings of SEB 2019. Smart Innovation, Systems and Technologies. Vol.163 (pp.319-326). Hungary, Budapest, 4-5 July 2019. Singapore: Springer Nature Singapore Pte Ltd., 2020, DOI:10.1007/978981-32-9868-2_27

11. Pḷaviņa, B., \& Actiņa, G. (2020). Implementation of Energy Efficiency Management System in Multi-Storey Residential Houses in Littoral Regions of Latvia. Baltic Journal of Real Estate Economics and Construction Management, 8 (1), 1-11. DOI: 10.2478/ bjreecm-2020-0001

12. Hernandez, P., Burke, K., \& Owen Lewis, J. (2008). DevelopmentofEnergy Performance Benchmarks and Building Energy Ratings for Non-Domestic Buildings: An Example for Irish Primary Schools. Energy and Buildings, 40 (3), 249-254. https://doi. org/10.1016/j.enbuild.2007.02.020

13. Martinaitis, V., Rogoža, A., \& Bikmanien I. (2004). Criterion to Evaluate the "Twofold Benefit" of the Renovation of Buildings and their Elements. Energy and Buildings, 36 (1), 3-8. https://doi.org/10.1016/S03787788(03)00054-9 
14. Central Statistical Bureau. (n.d.). MultiApartment Residential Buildings in Latvia. Available at http://data1.csb.gov. lv/pxweb/lv/rupnbuvn/rupnbuvn__nek ip/?tablelist=true. 2020

15. Altum: Development Finance Institution. (2020). The Programme for Improving Energy Efficiency in Multi-Apartment Residential Buildings. Available at https://www.altum.lv/en/services/energyefficiency/energy-efficiency-in-multiapartment-buildings/about-the-programme/
16. Ministry of Economics of the Republic of Latvia. (2014-2019). Videjjais apkures patēriņš èkās. Available at https://www. em.gov.lv/lv/nozares_politika/majokli/ petijumi_statistika/videjais_apkures paterins_ekas_uz_01_03_2014_/ 